\title{
Ectopic Adrenal Tissue in the Spermatic Cord in Pediatric Patients: Surgical Implications
}

\author{
Roberto Mendez, Manuel G. Tellado, Ivan Somoza, Jorge Liras, A. Sanchez-Abuin, Ernesto \\ Pais, Diego Vela
}

Pediatric Urology, Department of Pediatric Surgery, Children's Hospital Teresa Herrera, Complexo Hospitalario Juan Canalejo, A Coruna, Spain

\begin{abstract}
Objective: To study the incidence and relevance of ectopic adrenal tissue in pediatric patients who underwent groin surgical explorations.

Materials and Methods: We studied 1120 patients with groin surgical explorations during a period of 8 consecutive years. Patients' clinical data and histological findings were analyzed.

Results: We found ectopic adrenal tissue in 13 patients in 1120 groin surgical exploration (1.16\%). Of the 13 cases, 5 were diagnosed as having undescended testes, 6 inguinal hernia and 2 communicating hydrocele. Median age at diagnosis was 5.6 years. Histological sections showed adrenal cortical tissue with no medulla present.

Conclusion: Based on the clinical implications of those adrenal rests it is mandatory the removal of this ectopic tissue whenever encountered during surgical interventions in the groin region in children.
\end{abstract}

Key words: adrenal glands; aberrant tissue; spermatic cord; child

Int Braz J Urol. 2006; 32: 202-7

\section{INTRODUCTION}

Ectopic adrenal tissue along the spermatic cord is a rare diagnosis in childhood. Since Morgagni's first description in 1740, only 95 additional cases have been reported in the available English literature, most of them in pediatric patients. Overall incidence in different studies varies from $1 \%$ to $9.3 \%$ of the patients who underwent groin surgical explorations (Table-1). Adrenal cortex rests may undergo hyperplasia in patients with increased adrenocorticotropic hormone $(\mathrm{ACTH})$ production and potentially malignant neoplasm.

We report thirteen cases of accessory adrenal located in the spermatic cord. The clinical and surgi- cal implications of this uncommon anomaly are discussed and a through review of the literature is made.

\section{MATERIAL AND METHODS}

From April 1997 to March 2005, we studied 1120 pediatric patients under 14 years of age, who underwent surgical groin exploration for undescended testes, communicating hydrocele or inguinal hernia. We reviewed the clinical charts of patients encoded as having ectopic adrenal in the database of our department.

The surgical operation for inguinal hernia, communicating hydrocele and cryptorchidism were 
carried out using standard procedure opening the external oblique fascia and dissecting the spermatic cord elements. No surgical efforts of more aggressive cranial dissection of the spermatic cord were made.

Data about operation performed, age, gender and pathological characteristics of the nodules were recorded. All the pathological tissue founded along the spermatic cord were analyzed by the pathology department of our hospital and confirmed as ectopic adrenal cortical rests using the hematoxylin-eosin stain.

Data were registered using Microsoft Excel ${ }^{\circledR}$ database and analyzed using SPSS ${ }^{\circledR} 11.0$ software. The chi-squared statistical test was used for comparison of incidence between diagnostic groups with $\mathrm{p}$ value $<0.001$

\section{RESULTS}

We found ectopic adrenal tissue in 13 patients of 1120 groin surgical exploration $(1.16 \%)$. All the cases were boys with none detected in girls. No cases of bilateral nodules were demonstrated in patients submitted for bilateral procedures. Of the 13 cases, 5 were diagnosed as having undescended testes, 6 inguinal hernia and 2 communicating hydrocele. Median age at diagnosis was 5.6 years (range 2 to 10 years). There was no statistically significant difference concerning the incidence in the diagnostic groups studied $(\mathrm{p}=$ $0.37)$.

All the nodules were located along the spermatic cord in proximity to the deep inguinal ring embedded in the cremasteric fibers near the deferens. The appearance of the ectopic adrenal tissue was similar in all the patients: a small in size $(<3 \mathrm{~mm})$ bright yellowish soft nodule clearly different in color and consistency from the fat (Figure-1).

Histological sections of the excised nodules showed adrenal cortical tissue consisting of three layers of adrenal cortex (glomerulosa, fasciculata and reticularis) with no medullary tissue present (Figure2). Two cases of focal calcifications were observed (Figure-3).

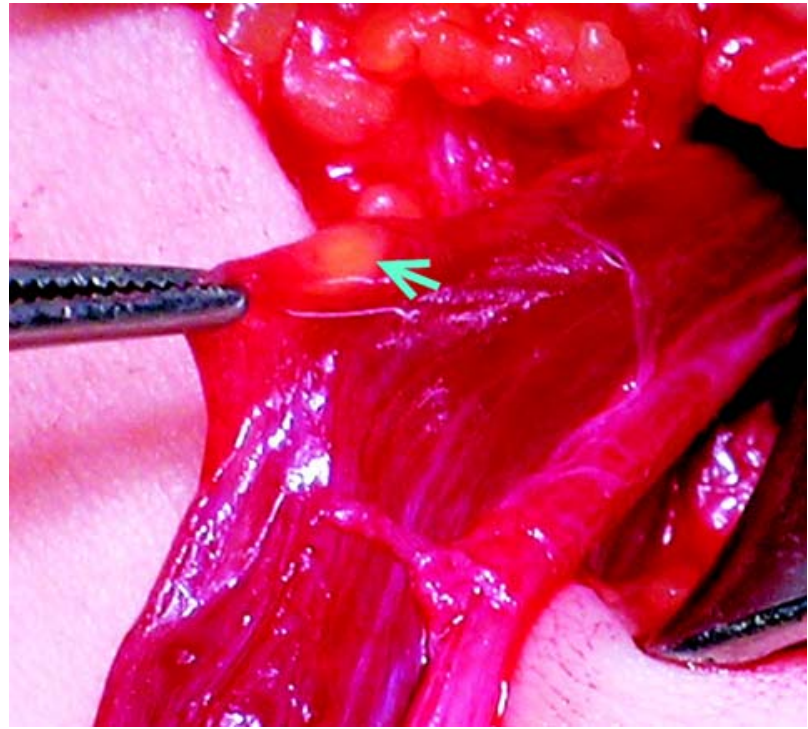

Figure 1 - Intraoperative photograph during orchidopexy for criptorchidism. Arrow and forceps tip marks the well-defined yellow nodule.

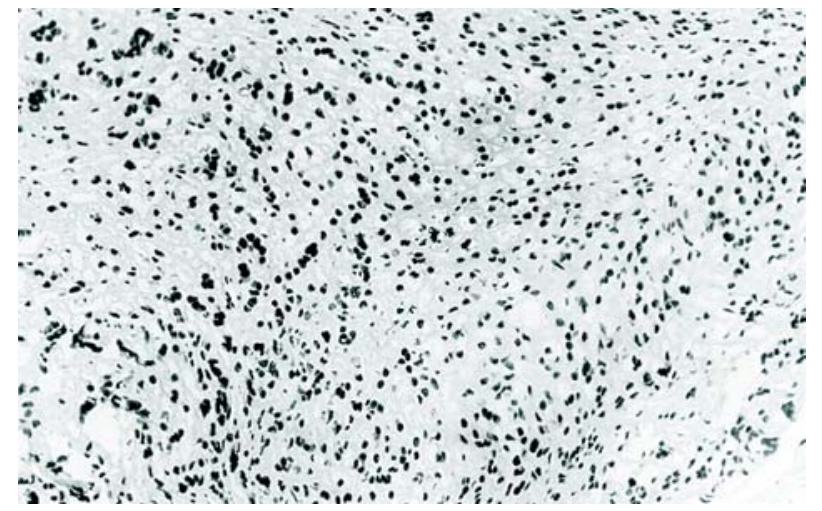

Figure 2-Histologic section with lipid rich cortical cells clearly seen with no medullary tissue (HE, X150).

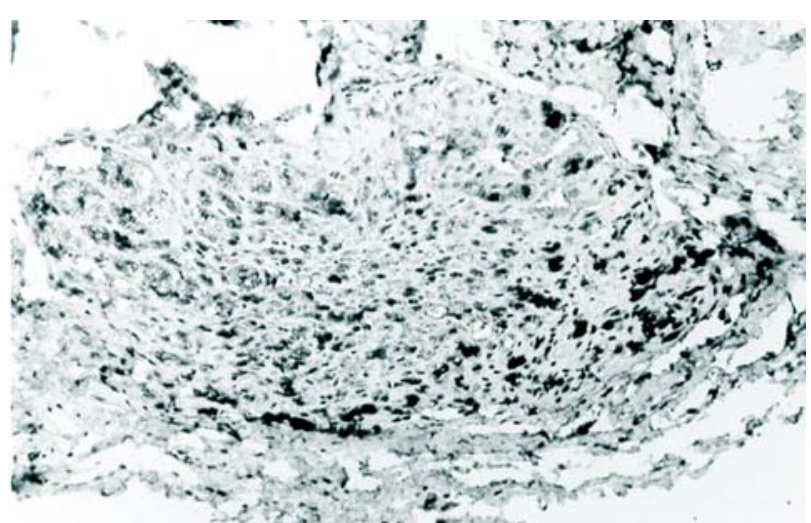

Figure 3 - Histologic section showing encapsulated adrenal cortical tissue with focal calcification (HE, X50). 


\section{COMMENTS}

Aberrant adrenal tissue is not a rare finding near the adrenal gland proper but the occurrence of ectopic adrenal tissue in structures around the spermatic cord and testis is rather rare. In 1740, Morgagni first described yellowish nodules resembling adrenal tissue adjacent to the main glands (1). Since then, several accounts have been published locating ectopic adrenal tissue in various sites, most frequently in relation to the kidney, but less than 100 cases have been reported near the genital structures (Table-1). Of these, approximately 80 cases have been described in male genital structures in childhood (234). Instead this low rate of incidence, probably this entity is more frequent than we thought before, and likely many cases like these have not been reported. The lower incidence in girls is not easy to explain but may reflect differences in underlying diagnosis (29).

Table 1 - Cases of adrenal rests in the structures around the testis reported in the available literature.

\begin{tabular}{|c|c|c|c|c|}
\hline Authors and Year & Cases Reported & Location & Gender & Mean Age \\
\hline McLennan (1919) (2) & 6 pediatric cases & Hernial sacs & $4 \mathrm{M}, 2 \mathrm{~F}$ & No data \\
\hline Gualtieri \& Segal (1949) (19) & 1 adult case & Spermatic cord & Male & No data \\
\hline Dahl \& Bahn (1962) (3) & 11 cases in infants & Paratestis & Males & Infants \\
\hline Schechter (1968) (1) & 1 adult case & Inguinal & Male & No data \\
\hline Mininberg \& Dattwyler (1973) (4) & 1 case in a child & Inguinal & Male & Newborn \\
\hline Feldman et al. (1975) (5) & 1 pediatric case & Spermatic cord & Male & $10 \mathrm{y}$ \\
\hline Gutowski \& Gray (1979) (23) & 5 adult cases & Inguinal & Males & No data \\
\hline Anderson \& McLean (1980) (13) & 1 adult case & Inguinal & Male & $53 \mathrm{y}$ \\
\hline Mares et al. (1980) (6) & 12 pediatric cases & Spermatic cord & Males & No data \\
\hline Lodeville et al. (1981) (20) & 1 adult case & Genital & Males & No data \\
\hline Landry (1982) (25) & 1 adult case & Paratesticular & Male & $30 y$ \\
\hline Lambrecht \& Kortmann (1983) (28) & 1 pediatric case & Inguinal & Male & $7 y$ \\
\hline Brunning (1984) (22) & 1 pediatric case & Spermatic cord & Male & $5 \mathrm{y}$ \\
\hline Czaplick et al. (1985) (13) & 2 adult cases & Inguinal & Males & $18 \mathrm{y}$ \\
\hline Wolloch et al. (1986) (7) & 1 case in a child & Spermatic cord & Male & $9 y$ \\
\hline Delmas \& Dauge (1986) (17) & 2 adult cases & Spermatic cord & Males & $28 \mathrm{y}$ \\
\hline Ferro et al. (1988) (8) & 13 pediatric cases & Inguinal & Males & No data \\
\hline Vestita et al. (1989) (9) & 1 case in a child & Spermatic cord & Male & $5 \mathrm{y}$ \\
\hline Miersch et al. (1989) (27) & 1 adult case & Spermatic cord & Male & $40 \mathrm{y}$ \\
\hline Benvenuti et al. (1991) (18) & 1 adult case & Perideferential & Male & $21 \mathrm{y}$ \\
\hline Roggia et al. (1991) (10) & 1 pediatric case & Perideferential & Male & $11 \mathrm{y}$ \\
\hline Litovka et al. (1991) (11) & 1 case in a child & Spermatic cord & Male & $3 y$ \\
\hline Habuchi et al. (1992) (12) & 1 pediatric case & Spermatic cord & Male & $6 y$ \\
\hline Roca et al. (1993) (26) & 6 adult cases & Spermatic cord & Males & No data \\
\hline Okur et al. (1995) (33) & 9 pediatric cases & Spermatic cord & Males & $3.2 \mathrm{y}$ \\
\hline Basar et al. (1997) (24) & 1 adult case & Near testis & Male & No data \\
\hline Ventura et al. (1998) (32) & 1 adult case & Spermatic cord & Male & $42 \mathrm{y}$ \\
\hline Savas et al. (2001) (31) & 11 pediatric cases & Inguinal region & $8 \mathrm{M}, 3 \mathrm{~F}$ & No data \\
\hline Oguzkurt et al. (2002) (30) & 4 pediatric cases & Hernial sacs & $3 \mathrm{M}, 1 \mathrm{~F}$ & No data \\
\hline Mari et al. (2004) (34) & 1 adult case & Spermatic cord & Male & $40 \mathrm{y}$ \\
\hline Sullivan et al. (2005) (29) & 29 pediatric cases & Spermatic cord & Males & No data \\
\hline Actual Report (2005) & 13 pediatric cases & Spermatic cord & Males & $5.6 \mathrm{y}$ \\
\hline
\end{tabular}


Embriologically the adrenal develops from 2 primordia: the cortex arises from the mesoderm and the medulla from ectoderm of the neural crest. The primitive cortex is formed during the 4th and 5th weeks from mesothelial cells formed between the mesentery root and the developing gonad that proliferate, separate and condense in the mesenchyma of the dorsal abdominal wall. Another group of cells from the same area is added to this later to form the definitive cortex. Cells from the neural crest invade the primitive cortex to form the medulla. Encapsulation of the medulla occurs late in fetal development $(7,10,13)$. It is generally accepted that these adrenal rests were due to mechanical separation and displacement of portions of cortical tissue during migration and descent of the sex glands in the male embryonic development. They also may have a multiple primordial origin from pluripotent cells in the original locations $(13,14)$. Some heterotopic tissue remains in the area of the adrenal gland near the kidney, but others may migrate with the genitalia descent to the pelvis and scrotum. Some authors estimated that these rests may be present in $50 \%$ of newborns but most of them become atrophic by adult life $(1,15)$. Other organs in which an accessory adrenal has been found are the colon, pancreas, retroperitoneum, liver, broad ligament and celiac plexus $(7,16)$.

The pathologic appearance of this tissue is characteristic. The findings consisted of a thin yellowish nodule 1 to $5 \mathrm{~mm}$ in diameter embedded in cremasteric fibers (13). Adrenal rests situated far from the original gland are composed entirely of cortical adrenal tissue with no evidence of medullary cells found in these rests, but the more proximal may contain medulla. Usually a capsule of connective tissue with small blood vessels can be seen surrounding these nodules (3). Of the three cortical layers, predominate the fasciculata and glomerulosa. The reticularis layer is usually seen only in older children (6).

Most cases of ectopic adrenal tissue in spermatic cord have been found incidentally during surgical procedures (like herniotomy, orchiopexy, etc) in the inguinoscrotal region $(17,18)$. Examples of heterotopic tissues in autopsies have been reported in adults and children usually underneath the capsule of the kidney $(1-3,6,16)$.
The clinical implications of those rests are essential in the surgical approach of the patients. Some authors cite a compensatory functional hypertrophy of these tissues in rats and human beings in which both adrenals were extirpated $(1,6)$. In patients who have undergone bilateral adrenalectomy due to pathologic $\mathrm{ACTH}$ production, compensatory hyperplasia of the ectopic adrenal tissue may be responsible for the recurrence of the disease $(7,10)$. Another clinical aspect is the possibility of formation and development of malignant diseases in the ectopic adrenal cells $(13,19-21,34)$. Although the occurrence of neoplasm in ectopic adrenal nodules is far from common, pheochromocytoma, Leydig cell's tumor and adrenal adenoma has been reported $(21,29,35)$.

Based on these facts, we think that removal of ectopic adrenal tissue in the spermatic cord would be warranted whenever encountered during surgical operations in inguinal region. It is very easy to excise the adrenocortical ectopic tissue during the groin surgery; however, meticulous dissection of the spermatic cord should not be performed in order to avoid the damage of the spermatic vessels and deferens. The nodule is usually embedded in the cremasteric fibers of the spermatic cord, very close to the deferens and attached to the hernia sac and it is very simple to have it dissected free without vascular injury. The lesion of the deferens has not been reported in the literature. In agreement with others authors, we consider that it is also important for urologist to keep in mind the possibility that a nodule around the spermatic cord may be ectopic adrenal tissue. It is reasonable to excise this nodule without jeopardizing the viability of the spermatic cord structures.

\section{CONFLICT OF INTEREST}

None declared.

\section{REFERENCES}

1. Schechter DC: Aberrant adrenal tissue. Ann Surg. 1968; 167: 421-6. 
2. McLennan A: On the presence of adrenal rests in the walls of hernial sacs. Surg Gynec Obst. 1919; 29: 387.

3. Dahl EV, Bahn RC: Aberrant adrenal cortical tissue near the testis in human infants. Am J Pathol. 1962; 40: 587-598.

4. Mininberg DT, Dattwyler B: Ectopic adrenal tumor presenting as torsion of the spermatic cord in a newborn infant. J Urol. 1973; 109: 1037-8.

5. Feldman AE, Rosenthal RS, Shaw JL: Aberrant adrenal tissue: an incidental finding during orchiopexy. J Urol. 1975; 113: 706-8.

6. Mares AJ, Shkolnik A, Sacks M, Feuchtwanger MM: Aberrant (ectopic) adrenocortical tissue along the spermatic cord. J Pediatr Surg. 1980; 15: 289-92.

7. Wolloch Y, Ziv Y, Dintsman M: Accessory adrenal: an incidental finding during orchiopexy. Panminerva Med. 1986; 28: 47-9.

8. Ferro F, Bosman C, Caterino S et al. Ectopia corticosurrenale nel cordone spermatico: Solo una curiositá anatomica? Acta Urol Ital. 1988; 5: 415-7.

9. Vestita G, Veneziani P, Manghisi D, Scavelli V, Sorino F, Gabrieli G, et al.: A rare occurrence of adrenal ectopy im the spermatic cord. A short clinical note. G Chir. 1989; 10: 499-500.

10. Roggia A, Marandola P, Broggini P, Bono P, de Francesco O, Rovati L: Ectopic adrenal cortex tissue in the spermatic cord: clinico-surgical implications. Arch Esp Urol. 1991; 44: 1165-6.

11. Litovka VK, Zhurilo IP, Khudiakov AE: Atopic adrenal tissue in the testicle of a small child with cryptorchism. Khirurgiia (Mosk). 1991; 8: 164.

12. Habuchi T, Mizutani Y, Miyakawa M: Ectopic aberrant adrenals with epididymal abnormality. Urology. 1992; 39: 251-3.

13. Anderson JR, Ross AH: Ectopic adrenal tissue in adults. Postgrad Med J. 1980; 56: 806-8.

14. O'Crowley CR, Martland HS: Adrenal heterotopia rests and so-called Grawitz tumors. J Urol. 1943; 50: 756-68.

15. Czaplicki M, Bablok L, Kuzaka B, Janczewski Z: Heterotopic adrenal tissue. Int Urol Nephrol. 1985; 17: 177-81.

16. Nelson AA: Accessory adrenal cortical tissue. Arch Pathol 1939; 27: 955-9.

17. Delmas V, Dauge MC: Accessory adrenals in the spermatic cord. Apropos of 2 cases. Ann Urol (Paris). 1986; 20: 261-4

18. Benvenuti S, Sepich CA, Cecchi M, Castagna M, Viacava P, Fiorentini L: Peri-deferential ectopic adrenal gland. Apropos of a case. J Urol (Paris). 1991; 97: 107-8.
19. Gualtieri T, Segal AD: Case of adrenal type tumor of spermatic cord. J Urol. 1949; 61: 949-5.

20. Lodeville D, Zaroli A, Lampertico P: Adenomatoid tumor of the male genital tract: report of three cases, one associated with adrenal cortical rest. Pathologica. 1981; 73: 629-37.

21. Vela Navarrete R, Barat A, Berrocal A, Lopez de Alda A, Quezada F: Testicular adrenal rests tumor: a difficult diagnosis. Actas Urol Esp. 1990; 14: 146-8.

22. Bruning H, Kootstra G, Walther FJ, Arends JW: Ectopic adrenocortical tissue along the spermatic cord. Z Kinderchir. 1984; 39: 269-70.

23. Gutowski WT 3rd, Gray G Jr: Ectopic adrenal in inguinal hernia sacs. J Urol. 1979; 121: 353-4.

24. Basar M, Erdogan S, Aydoganli L, Basar H, Kulacoglu S, Akalin Z: Aberrant adrenal cortical tissue adjacent to immature testis. Arch Ital Urol Androl. 1997; 69: 141-2.

25. Landry GS: Case for diagnosis: ectopic adrenal tissue in testicular adnexa. Mil Med. 1982; 147: 679-80.

26. Roca Suarez A, Alvarez Ossorio JL, Del Toro Bacerra JA, Maximiano Vasquez R, Gordon Laporte R: Adrenal ectopia in the spermatic cord. Actas Urol Esp. 1993; 17: 584-7.

27. Miersch WD, Vogel J, Molitor D, Winter P: Ectopic adrenal cortex tissue. Z Urol Nephrol. 1989; 82: 487 90 .

28. Lambrecht W, Kortmann KB: Incidence and significance of accessory adrenal tissue in the inguinal region in childhood. Chirurg. 1983; 54: 39-41.

29. Sullivan JG, Gohel M, Kinder RB: Ectopic adrenocortical tissue found at groin exploration in children: incidence in relation to diagnosis, age and sex. BJU Int. 2005; 95: 407-10.

30. Oguzkurt P, Oz S, Kayaselcuk F: Ectopic adrenal tissue: an incidental finding during inguinoscrotal operations in children. Hernia. 2002; 6: 62-3.

31. Savas C, Candir O, Bezir M, Cakmak M: Ectopic adrenocortical nodules along the spermatic cord of children. Int Urol Nephrol. 2001; 32: 681-5.

32. Ventura L, Leocata P, Hind A, Greco I, Ventura T: Ectopic adrenal tissue in the spermatic cord. Case report and review of the literature. Arch Ital Urol Androl. 1998; 70: 15-8.

33. Okur H, Kucukaydin M, Kazez A, Kontas O: Ectopic adrenal tissue in the inguinal region in children. Pediatr Pathol Lab Med. 1995; 15: 763-7.

34. Mari M, Cagnazzi E, Bollito E, Bellina M: Ectopic adrenal cortex tissue in the spermatic cord in association with testicular cancer. Urol Int. 2004; 73: 191-2. 
35. Abe T, Matsuda H, Shindo J, Nonomura K, Koyanagi $\mathrm{T}$ : Ectopic pheochromocytoma arising in the spermatic cord 5 years after removal of bilateral carotid body tumors and adrenal pheochromocytomas. Int $\mathrm{J}$ Urol. 2000; 7: 110-1.
Accepted after revision: January 11, 2006

\author{
Correspondence address: \\ Dr. Roberto Méndez \\ Department of Paediatric Surgery \\ Complexo Hospitalario Universitario de Santiago \\ Avda. Choupana s/n. \\ 15706 Santiago de Compostela, Spain \\ E-mail: roberto.mendez.gallart@ sergas.es
}

\section{EDITORIAL COMMENT}

Heterotopic or ectopic adrenal cortical tissue (EACT) are found in the upper abdomen or anywhere along the path of descent of the gonads. The locations where EACT can be found are: celiac axis area $(32 \%)$; broad ligament $(23 \%)$; adnexa of the testes $(7.5 \%)$; kidney (subcapsular upper pole) $(0.1 \%-6 \%)$ and spermatic cord $(3.8 \%-9.3 \%)(1,2)$. These anatomic locations can be explained on an embryologic basis given the close spatial relationship between the developing kidneys and adrenal glands. There are even bizarre anatomic sites where one can find these EACT, such as: placenta, liver, lung and intracranial cavity (1). Usually these adrenal rests are found incidentally during inguinal operations and present macroscopically as bright yellow small nodules (1-5mm in diameter) and microscopically as lipid rich cortical cells without a medullary component (1-3). These rests have some clinical significance as they may undergo marked hyperplasia in conditions associated with excessive ACTH production, and occasionally may give rise to neoplasms. The overall incidence of EACT in different studies varies from $1 \%$ to $9.3 \%$ in pediatric patients. These big series in the literature stick out the importance of recognizing and removing these EACT, whenever encountered, owing to the clinical relevance of these ectopies (2-5).

\section{REFERENCES}

1. Lack EE. Heterotopic and Accessory Adrenal Tissues In: Lack EE, (ed.), Tumors of the Adrenal Gland and Extra-Adrenal Paraganglia. Fascicle 19, third series. Washington, DC: Armed Forces Institute of Pathology. 1997; pp. 34-5.

2. Mares AJ, Shkolnik A, Sacks M, Feuchtwanger MM: Aberrant (ectopic) adrenocortical tissue along the spermatic cord. J Pediatr Surg. 1980; 15: 289-92.

3. Savas C, Candir O, Bezir M, Cakmak M: Ectopic adrenocortical nodules along the spermatic cord of children. Int Urol Nephrol. 2001; 32: 681-5.

4. Sullivan JG, Gohel M, Kinder RB: Ectopic adrenocortical tissue found at groin exploration in children: incidence in relation to diagnosis, age and sex. BJU Int. 2005; 95: 407-10.

5. Ferro F, Bosman C, Casterino S et al. Ectopia corticosurrenale nel cordone spermatico: Solo una curiositá anatomica? Acta Urol Ital 5: 415-417, 1988.

Dr. Patrícia S. de Matos

Department of Pathology,

School of Medicine, State University of Campinas

São Paulo, Brazil 